\title{
Middle Sepik music and musical instruments in the context of Melanesia
}

La musique du Moyen Sepik et ses instruments dans le contexte mélanésien

\section{Raymond Ammann}

\section{(2) OpenEdition \\ Journals}

\section{Electronic version}

URL: http://journals.openedition.org/jso/8411

DOI: $10.4000 /$ jso.8411

ISSN: $1760-7256$

\section{Publisher}

Société des océanistes

\section{Printed version}

Date of publication: 15 July 2018

Number of pages: $179-188$

ISBN: 978-2-85430-135-9

ISSN: 0300-953x

\section{Electronic reference}

Raymond Ammann, " Middle Sepik music and musical instruments in the context of Melanesia », Journal de la Société des Océanistes [Online], 146 | 2018, Online since 15 July 2020, connection on 23 July 2020. URL : http://journals.openedition.org/jso/8411 ; DOI : https://doi.org/10.4000/jso.8411

(c) Tous droits réservés 


\title{
Middle Sepik music and musical instruments in the context of Melanesia
}

by

\author{
Raymond AMMANN*
}

\begin{abstract}
The ceremonial flutes and the large slit drums are the most significant musical instruments of the Sepik River region. The sculptures and decorations on the instruments link them to the mythical world and their sounds represent the voices of ancestor spirits. Furthermore, a detailed music analysis reveals the miscellaneous and complex ways of how the ceremonial music represents this society's structure and its driving force. This contribution is based on the findings from a short field trip in the 1980 and the study of relevant publications.
\end{abstract}

KeYwords: ethnomusicology, slit drums, bamboo flutes, music, Melanesia

\section{Melanesia}

Melanesia's language diversity can be expanded to music and dance, as each language area has its local style of songs and dances. Melanesian music and dance are so versatile and multifunctional that it is impossible to characterize it in a few sentences. However, one feature that would best denote Melanesian music is its representing content. For songs, music and dances ${ }^{1}$ this content is expressed in words, structures and sound qualities. For musical instruments, the representing content lies in their visual appearance. In the first part of this contribution, a short presentation of typical Melanesian musical features will provide the background for the understanding of the second part, in which I will

\section{RÉSUMÉ}

Les flùtes cérémonielles et les grands tambours à fente sont les instruments les plus significatifs de la Rivière Sepik. Leurs sculptures et leurs décorations les relient au monde mythique et leurs sons représentent les voix des esprits des ancêtres. En plus, une analyse musicale profonde montre les moyens diversifiés et complexes avec lesquels la musique cérémonielle représente non seulement la société elle-même mais aussi sa force motrice. Cette contribution est basée sur une courte recherche de terrain dans les années 1980 et une étude de la littérature importante.

Mots-CLÉS : ethnomusicologie, tambours à fente, flûtes en bambou, musique, Mélanésie

point out the characteristics of the music culture at the Sepik River in Papua New Guinea.

\section{Melanesian musical instruments}

From the four large groups of musical instruments defined by Hornbostel and Sachs in 1914, only the percussion instruments (idiophones) and wind instruments (aerophones) are well presented in Melanesia. Skin drums (membranophones) exist in parts of Melanesia and string instruments (chordophones) are very rare. They are represented in the form of the musical bow and a basic zither. The Europeans brought string instruments

1. Melanesian names for "musical" performances refer mostly to singing and dancing as a unit.

*University of Innsbruck; raymond.ammann@uibk.ac.at 
to the Pacific and on some islands, these were well accepted and adapted by the Melanesians for their own needs. These string instruments are mainly the guitar and the ukulele. Together with self-made percussion instruments they are played in "string bands". Such non-electrified bands are omnipresent in Melanesia (Ammann, 1997, 1998, 2013; Webb, 1993; Crowdy, 2005) and there are local differences in the instrumental use and function. However, all over Melanesia the string bands play a mixture of traditional Melanesian and European popular music and their songs are often in one of the local languages.

\section{Melanesian slit drums}

In Melanesia the most impressive musical instruments are the large slit drums. They are found in the north of Papua New Guinea and on most of the nearby islands, their diffusion expands further south, passing the Solomon Islands and reaches as far as the island of Efate in Central Vanuatu. In the southern parts of Vanuatu and in New Caledonia slit drums did not exist ${ }^{2}$. The term slit drum refers in Melanesia to large hollow tree trunks of several meters in length with a slender slit as well as to small hand-held pieces of bamboo with a longitudinal slit in the internode. In some regions of Vanuatu and Solomon Islands the large slit drums are played polyrhythmically in ensembles of different sized instruments.

On some islands in central Vanuatu the largest drums of an ensemble are set in an upright position but on the other Melanesian islands all the drums are lying on the ground ${ }^{3}$, in some cases on a piece of wood. The standing drums in Vanuatu as well as the large lying slit drums in Papua New Guinea are decorated with fine sculptures that indicate their strong relationship to the ancestral world. The undecorated drums of Vanuatu and Solomon Islands stand in a minor relationship to the ancestral world. Still, on one hand, slit drums are played in ceremonies with the function to call the ancestor spirits and, on the other hand, they can have the profane function to send out acoustical signals and messages to the population or even to call individual persons (see further down in this contribution). As women are excluded from the men's ceremonial activities in Melanesia, they are not allowed to approach ceremonial slit drums. In regions where the slit drums are of a lower taboo status, for example on the islands of Pentecost, Ambae or Maewo in Vanuatu, women can approach them.
The particularity of the Melanesian slit drums besides their big size is their large volume of the hollow interior combined with a very narrow slit. Such instruments are much harder to build (to hollow out the drum's interior through a narrow slit is very difficult and time consuming) than, for example, the smaller sized slit drums in Polynesia, with a much wider opening, but their sound travels much further. In Melanesia - as well as in Polynesia - the slit drums accompany dancing and their sound needs only to reach the dancers and the audience in a radius of about 50 meters. The large Melanesian drums on the other hand have furthermore the function to send messages and signals to the population and therefore their sound needs to travel further than the dance field. In good conditions the sound of large slit drums can travel for kilometers, for example, from the island of Ambrym to the neighbouring island of Malakula, twenty to forty kilometres away (Ammann, 2012: 166).

\section{Melanesian flutes}

On a global assessment, Melanesia holds the widest manifestation of flute types and panpipes of a large cultural area regarding the limited land mass. Some flute types are unique and exist only in certain regions and in other regions there are wide ranges of specifications of the same type of flutes. Unfortunately, today a great number of Melanesian flutes are no longer played and can only be found in museums. In comparison with the slit drums, flutes and panpipes are - with some exceptions in Papua New Guinea and some places in the Solomon Islands - not or not anymore used as ceremonial instruments. As for all flutes, their organological characteristics (length, bore, position of finger holes etc.) define the flute's fundamental pitch, timbre and intervals. For example, the unique flute from New Georgia in the Western Province of the Solomon Islands, that was painted by Edge Partington and entitled "Boy playing bamboo flute, New Georgia" (Edge-Partington, 1969 [1890-91] III: 31 , fig. 2$)^{4}$ measures $98.5 \mathrm{~cm}$ in length, is sideblown and has no finger holes. The musician covers the open distal end with the palm of hand of the stretched out left arm. Equally, the musicians who play the notched flute on the island of Ambrym in Vanuatu need to stretch out their arms, as the two finger holes are at the distal end and the flute is of such length that only the tip of the stretched out middle finger of the stretched-out arm can cover the distal finger hole. The flute is stopped at the distal end by the bamboo node (Ammann, 2012:

2. Polynesians working in New Caledonia play the Polynesian type of slit drums in their community dance groups.

3. Standing slit drums of three to four meters in length were apparently once common at the Upper Sepik River (Bogner, 1984: 11). However, there is no further substantiation to Bogners statement.

4. The picture corresponds to a photograph made by Sommerville (1897: 395). 
56). On the main island (Grande Terre) of New Caledonia, the ancient but unique Kanak flute ${ }^{5}$, earlier mistaken by some authors for a nose-flute (Ammann, 2007), is a side-blown instrument. It was not made from bamboo, as most Melanesian flutes are, but of a certain species of reed, which allows the instrument's curved form. The flute had only one finger hole at the farthest tip of the up to 120 centimetres long instrument. And as the stretched-out arm of the musician must reach this hole, the flute was bent (Ammann, 1996). These are only a few examples of Melanesian flutes; the mentioned particularity: to build the flutes as long as possible with the finger holes as close to the distal end and still be able to cover it with a stretched out hand and arm, can also be found on other flutes such as the shoulder flutes on Ambae (Ammann, 2012: 76), double flute on Ambae and Ambrym (Ammann, 2012: 79), end-blown flutes at the Oro Province in Papua New Guinea (Fischer, 1983: 197) and others. As every Melanesian flautist builds his own instrument, each flute is of individual length. Having the flutes - and therefore their air columns - as long as possible has the advantage to play higher up in the harmonic series. As a rule, the longer the air column the more harmonics can be produced. With each position of the finger hole, closed or open, a certain series of the harmonics can be played. The finger holes are positioned in such a way that the sections of the playable harmonic series by closed or open finger holes do interlock. In the case of the side-blown flute from the Solomon Islands where the opening end is closed by the palm of the hand, there are two different ranges of harmonic series, one with all the harmonics, when the tube is open, and one with only the odd harmonics, when the distal end is closed. With long flutes with a few finger holes at the distal end arranged in such a way that harmonic series do interlock it is possible to sound a large range of different tones. This leaves the instrument less fragile and makes its construction easy.

\section{Music and musical instruments at the Sepik River region}

Compared with the rest of Melanesia, the amount of different types of musical instruments at the Sepik River is outstanding. There exist a few types of instruments, that are unknown from other Melanesian regions, for example, a very rare idiochord stick zither, made of the large middle vein of a sago palm of which a thin band of the epidermis is set free, supported and set under tension with the help of a small stone pressed under the band (Spearritt, 1979: 231; Hornbostel, 1911: 385; Wirz, 1959: 59, fig. 82; Roesicke, 1914: 514), a idioglottic jew's harp reported by Neuhauss (1911, I: 385) for former "Kaiser Wilhelmsland" (northern part of PNG) and the surface of the scraped stick of the lime vessel used for accompanying songs (pers. observation). Other idiophones such as dried seeds, snail shells, pebbles etc. are mentioned by Reche (1913: 419 Nr. 6+7). The diversity and artistic conception of musical instruments in the Sepik region show parallels to other artistic creations of the region, especially to wooden carvings of which this region gains a worldwide reputation. The carvings represent characteristic motifs and representations of important mythological figures, so do the decorations on musical instruments.

Detailed lists of the musical instruments from New Guinea including the Sepik River region are available since Kunst (1931), Fischer (1958, 1983), Spearritt (1979, 2009), McLean (1994) and Niles (2006: 322-351). For this text, only those instruments from the Sepik River region that are related to ceremonies with a strong symbolic content are of interest. Still, it is not possible to draw a line between profane and ceremonial musical instruments, as this categorization differs even from one village to the next. Furthermore, several musical instruments are used in daily life and in ceremonies, we call these instruments semi-ceremonial.

\section{The "kundu"}

The handheld drum, "kundu"6, of the Sepik River region can be defined as a semi-ceremonial instrument. These slender hour-glass shaped drums that measures between 50 to $100 \mathrm{~cm}$ in length, with a smaller diameter in the middle part, are often decorated with carvings, related to the ancestral world. Nevertheless, the "kundu" is not stored in the men's house as are other ceremonial instruments. The drumhead has a relative small diameter and there is only one way to strike it, thus there is little variation in the timbre of the strokes. However, because of the narrow center of the tubular drums the drum's sound gains much resonance. In most cases the "kundu" accompanies the singing, for example, among the Iatmul the ceremonial singing (sagi) with certain repetitive rhythmical patterns or simply regular pulses. The drumming itself is not representing

5. I call this instrument Kanak flute, because it is a unique flute type that exists only on the main islands of New Caledonia and was/is played by the "Kanak", the Melanesians of New Caledonia. The flute is diffused on this island over several language areas where it is referred to by the vernacular names (Ammann, 1997: 38).

6. "Kundu" originally a Tok Pisin (one of the official languages of Papua New Guinea) term. In this article, the Tok Pisin terms are in single quote and the terms in Iatmul language in italics. 
the sound of a certain ancestor spirit, but the content of the accompanied song cycles might refer to mythical times and places.

The sagi song cycles, which are accompanied by the "kundu" consist of alternating solo and group singing. The content of the solo singing, sui, localizes the singing at a certain place in the mythological migration, it recites the personal names and the forms of appearance of a mythological being. For the group singing, namoi, all the initiated men participate under the guidance of the first singer (Wassmann, 1982: 36). For each specific occasion of a sagi performance, a certain extract of the sagi cycle is performed: for the inauguration of a canoe the vala sagi, for the inauguration of the men's house the ngego sagi (Wassmann, 1982: 41). The connection to the ancestor world is created by the content of the sagi songs, and the "kundu" drumming creates an acoustical background grid, which helps the singers to memorize the texts and structure of the songs and in a symbolic way to ensure the permanency of the activities that "took" place in the mythical times, as told in the sagi songs. Besides, the sound of the "kundu" creates the acoustical surrounding of that mythical world and for large ceremonies other musical instruments have the same function. For example, the wooden trumpet with a lateral embouchure is used as a voice modifier by calling through the tube (Fischer, 1958: 64; Reche, 1913: 426/439) ${ }^{7}$. The water drums at the middle Sepik are either carved cylindrical pieces of a hollowed out wooden trunk (cf. Peltier et al., 2015: 274-75) or they take the shape of inverted large bowls (Peltier et al., 2015: 273). While the cylindrical drums hit the surface of the water (in the river or in an artificial ditch) by being pushed down or thrown from above, it produces a splashing sound. The bowl-shaped ones are handled differently, creating a harsher sound. The sound made by the former in hitting the surface or by being removed from the water with the help of a rope attached, resembles that of a crocodile moving into or out of the water (Fischer, 1958: 8; Wirz, 1959: 59). In this case the sound indicates that - on a spiritual level - the mythical crocodile arrived in the world of the living people. Whereas such instruments like the water drums or the "kundu" represent the sounds of the mythical world, their sound is not said to be the direct voices of distinct ancestral spirits. As it is the case for the bull-roarer (Peltier et al., 2015: 268) ${ }^{8}$, and especially for the slit drums and the ceremonial flutes.

\section{Slit drums}

As mentioned above, slit drums are well distributed in Melanesia and those at the Sepik River are among the most prominent, because of their large size and their extraordinary carved decorations. Besides, the sound and the slit drums' polyrhythmic music are equally impressive.

A clan or a moiety of the Iatmul people at the middle Sepik might possess two pairs of drums, a pair of wagen-drums and a pair of mi-drums, both having their distinct forms and functions. The mi-drums are used to call individual persons or to send out signals. These drums are kept on the ground floor in the men's house. Although their use is profane and semi-ceremonial still they are used in some ceremonies and are decorated with carvings of mythological beings. Both endings of a drum show carvings of a smaller diameter than the drums body. The wagen-drums on the other hand are only used for important ceremonies and they are stored on the first floor in the men's house. They are formally very similar but somewhat smaller than the mi-drum. Their sculptures are often in human forms representing mythical protagonists thus the drum is a taboo instrument and charged with rules of how to approach it ${ }^{9}$.

The slit drums at the middle Sepik, both the miand the wagen-drums, are not struck but rather stamped. The drummer holds one beater upright in each hand and stamps it close to the drums "lip". The timbre changes according to the spot where the drum is stamped. When two drummers work on one drum, there is one on each side. On one lip the drums possess a thickening inward which changes the timbre when struck on that spot. Frequently the drums are stamped closer to the end of the slit, which leaves the major part of the drum to vibrate freely. And as both sides of the drums are stamped by two drummers, the side with the thickening produces a duller sound than the other side. Equally, the drums rest on two pieces of wood and their bodies do not touch the ground. In this way, even the lower parts of the drums can vibrate. Beating or stamping these drums demands strong physical effort and for day- and nightlong beating the musicians change at about every 20 minutes. To continue the music when the drummers change, the two men hold the beaters and beat the drum for a while together, until the drummer who takes over has adapted to the tempo and the correct rhythmical pattern.

7. Juillerat published his studies on trumpet of the Yafar at the northern region of the Border Mountains (West Sepik Province) in English. Here, flutes made from large bamboos are replaced by trumpets hollowed out from a single section of wood and blown at the end. These wooden trumpets were only used after head hunting (Juillerat, 1996: 4).

8. The bull-roarer is an esoteric instrument that is stored in the men's house and represents the voice of a certain mythical being (Gourlay, 1975: 19).

9. Patocchi (1990: 111) argues that there are reasons to believe the two drum types arrived at the middle Sepik by different migrations, as the mi-drum show similarities to the drums at the mouth of the Sepik River and the wagen-drums show similarities to the drums from the Upper Sepik. 


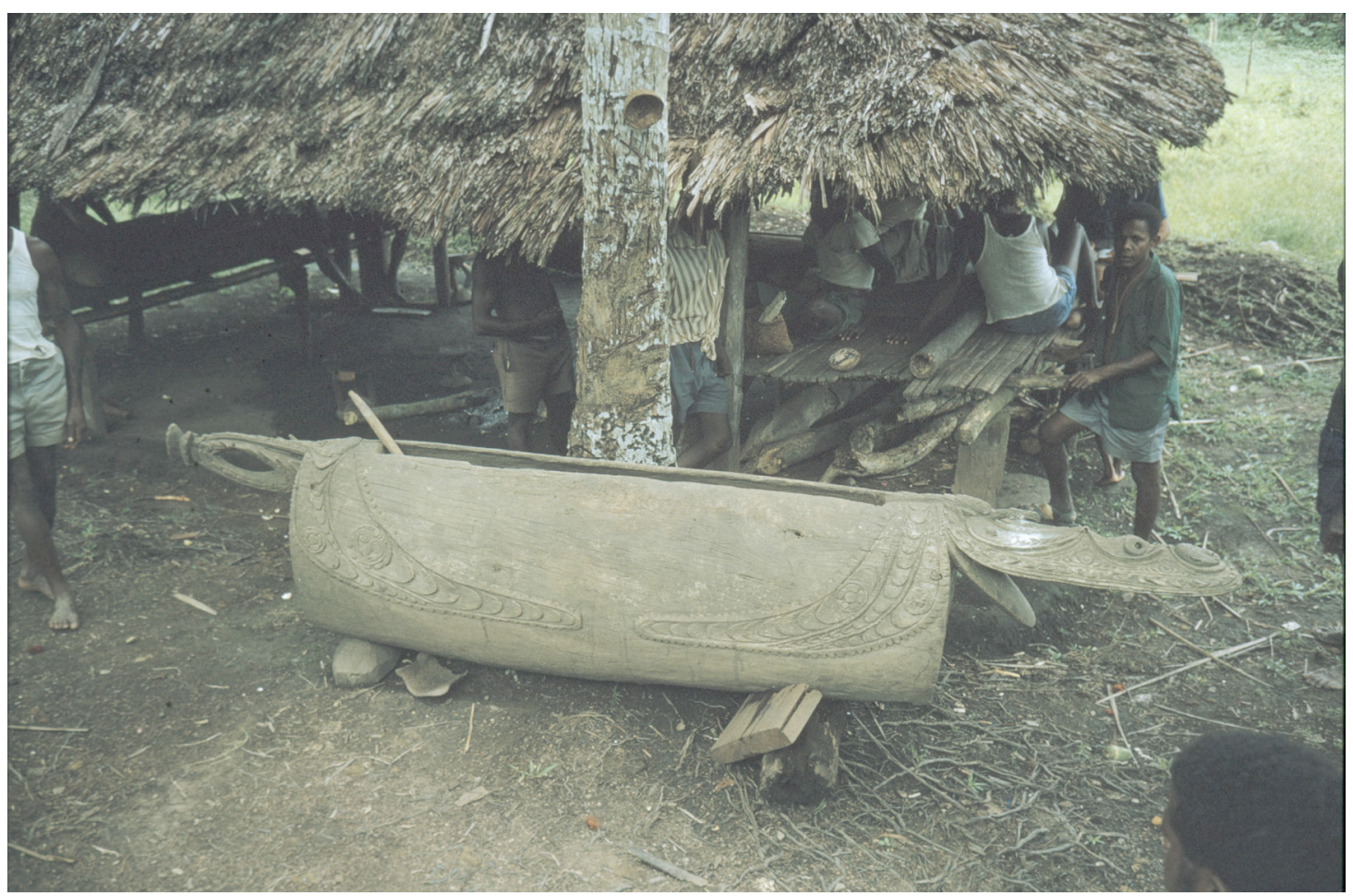

Рното 1. - Mi-drum "Yangumbui" from middle Sepik river, village Timbunke, with extensions representing a mythical being in appearance of a crocodile, 1966 (C) Gisela and Meinhard Schuster, Basel, image no. F 290/14)

\section{Drum music in ceremonies}

In the region of the middle Sepik River the most important event to beat the wagen-drums are the initiation of the male youth when they receive the scars and the status of grown up men. In earlier times, the wagen-drum also played an important role by calling the partners for a head hunt, by signaling their return (sabuk) and in the following rituals performed with the looted heads (Patocchi, 1990: 65). The main and probably more frequent ceremony that includes drumming, wagen mbangu, takes place - at least in the 1980s - in irregular intervals when a bad luck period comes over the village for example, death, sickness, etc. In this case the wagen-drums are struck for several days (Wassmann, 1982: 48).

The musical performance of the wagen-drums can be divided in three parts: a short introduction (ngawi kigandi), a long main part (wagen mbangu) and a short ending (mbangu and mumbekabak). For the ngawi kigandi, the drumming alternates between short and fast tremolo like patterns struck on two drums and short elements of standard patterns bruwagen on only one drum (Spearritt, 1979: 390). The main part of wagen mbangu consists of several repetitions of patterns called njangit which are introduced by bruwagen. Each njangit stands in relation to a certain ancestor spirit or to a mythical story. The njangit itself consists again of a series of certain patterns, which are separated by the bruwagen. The entire music is structured by an alternating structure of njangit and bruwagen. Spearritt says:

"Wagen mbangu can be described as a logical structure that allows repetition of a series of distinctive rhythmic patterns in such a way that the performance can last for as little as twelve hours or for as long as several days and nights without any break in continuity. The patterns are so devised that the rhythms hold interest and variety and are sufficiently differentiated to ensure that each njangit is distinctive from each other." (Spearritt, 1979: 423; 2009)

\section{Drum messages and signals in daily life}

In the egalitarian Iatmul society of the middle Sepik area the drums' individual message system is based on the person's clan affiliation. The following example of how these personal calls are structured is based on research in the village Aibom in $1987-88^{10}$. The system to call a person is based on existing clan and parental affiliation. For such calls the mi-drum are stamped with only one beater. Two different timbres are used, one when stamped close to the end of the slit providing a clear, high sound and one when stamped in the middle of the drum rendering a deep sound. The verbal sur-

10. As a student, together with my colleague, Claudio Patocchi, we had the chance to accompany professor Meinhard Schuster for a short field research in the village Aibom. 
rogate for these sounds are kai for deep and kin for the high sound. The large clan-owned collection of existing drum patterns is called ntshamba. Drumming the entire ntshamba is the sign that all the members of the clan should assemble. From each ntshamba certain patterns are separated and used as a tavik, which indicates a certain family within the clan. The ending of the tavik indicates the position of the person within this family. A personal signal consists of four parts (1-4):

1) Introduction pattern.

2) Tavik a pattern pointing out the person's family.

3) Three endings are possible $(a-b)$ which indicate the person's place in the family.

3a) Sawawu ending refers to the oldest man of the clan or the first-born boy. This pattern starts slow and accelerates. All the strokes are kai.

3b) Manclac ending refers to the second born son. It contains at least three accentuated kai strokes, then a kin stroke followed by sawawu pattern.

3c) Togumel ending refers to the third born son or mother of the sons. It contains several kai strokes in acceleration, followed by decrescendo and ends with the sawawu pattern.

4) Ending of the call, the pattern is identic with the introduction pattern.

Although the repertoire that provides the signal patterns is clan owned and refers to the history of the clan and therefore to the clan mythology, the signaling is performed on the semi-ceremonial mi-drum (Patocchi, 1990: 89) ${ }^{11}$.

\section{Ceremonial flutes}

There was and still is such a large variety of flute types at the Sepik that it is impossible to present here a complete list. In the museum of Basel, which holds one of the most important collections from the Sepik River region, are side-blown and notched flutes with and without finger holes as well as raft and bundle panpipes. Equally from the Sepik River region, Fischer (1958: 47) mentions end-blown flutes without finger holes and Neuhauss (1911:384) writes about a piston flute. Vessel flutes made from dried seeds (Peltier et al., 2015: 277; Wirz, 1952: 13) or out of clay (Bogner, 1984: 30/32) did exist at the Sepik as well. The most impressive flutes however are those large side-blown flutes used in ceremonies.

The term paired flutes, found in more recent literature (McLean, 1994: 23; Spearritt, 1982; Peltier et al., 2015: 272), indicates that the flutes are in general played in pairs of uneven length. However, in some villages these flutes are also played in groups rather than in pairs. We call them cer- emonial flutes, as did Reche for the first time in 1913 (Reche, 1913), because they are exclusively played during important ceremonies. However, with the major cultural changes in Papua New Guinea, it is possible, in some places, that these flutes are now played outside a ceremonial frame and even for visitors.

\section{Organology of ceremonial flutes}

The side-blown ceremonial flutes are the most outstanding in regard of their length, as they measure up to 250 centimeters and with very few exceptions they do not possess finger holes. The ceremonial flutes are made from bamboo with the distal end open and the upper end closed. The outer diameter of the flutes can reach $8 \mathrm{~cm}$. The blowing hole is round or oval and in the middle part of the uppermost internode. Some instruments are partially covered with rattan lianas and a piece of sculptured wood normally decorates the upper end. Especially ancient ceremonial flutes were well decorated with elaborated sculptures that show ancestor spirits or mythological protagonists standing in relation to the flute's name and which are acoustically represented by the flute's sound. The Swiss anthropologist Paul Wirz shows a series of such sculptures (Wirz, 1954: 101) which represent principally birds, crocodiles, snakes and human heads, some sculptures show combinations of such beings, for example bird and human. In this latter case, it is obvious that the same spirit is represented in various forms of appearance.

\section{Diffusion of ceremonial flutes}

Because of the vagueness of early references an area of diffusion of the Melanesian ceremonial flutes is difficult to draw. Most important publications about the diffusion of these flutes are Fischer (1958: 48; 1983: 86) and McLean (1994: 23). McLean limits their diffusion to the Sepik, Madang and Highland areas of Papua New Guinea as well as adjacent north coast areas of West Papua and refers to some places in the Bismarck Archipelago where ceremonial flutes exist (McLean, 1994: 39).

\section{The music of ceremonial flutes}

The Austrian Rudolf Pöch has been the first, in 1904, to record music of side-blown flutes in the north-east region of Papua New Guinea 


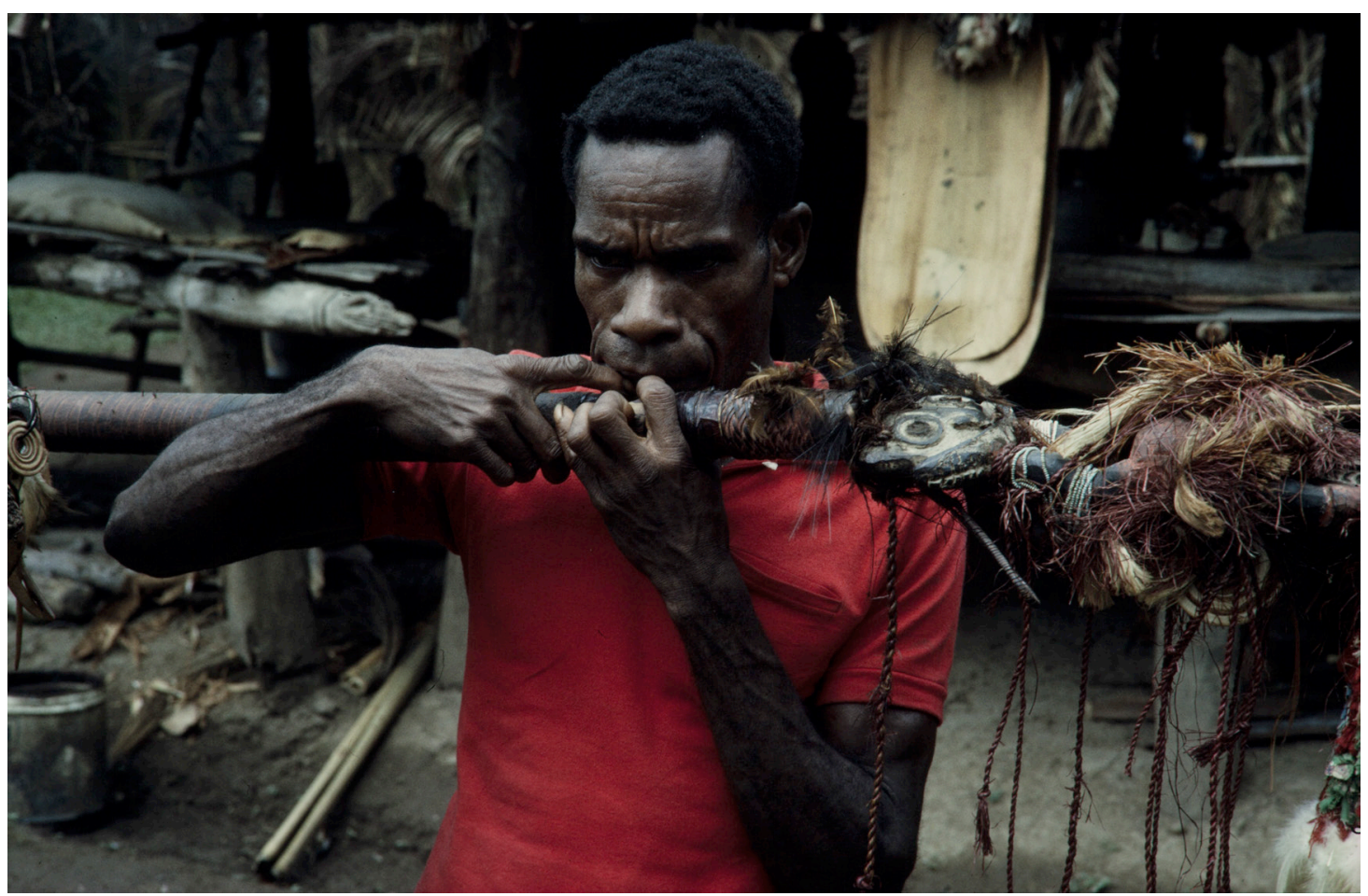

Рното 2. - A man plays a ceremonial flute with a beautifully decorated upper end. The position of the two indexes help to sound the harmonics, village Aibom, 1966 (C Gisela and Meinhard Schuster, Basel, image no. F 242/14)

(Graf, 1950: 86). And Graf used the flutes that were brought back to Vienna by Pöch for acoustical experiments (Graf, 1947: 87; 1950: 87). The German physician, Richard Neuhauss (1911), travelled between 1908 and 1910 in the region of the north-east coast and recorded songs and instrumental music. And Adolf Roesicke, a member of the Kaiserin-Augusta-Fluss-Expedition of 1912, recorded music and language examples at the Sepik River. Paul Wirz travelled several times to New Guinea and Papua New Guinea, brought several flutes back to Basel, and published articles on the subject (Wirz, 1952 and 1954; Schmidt, 1998: 257). Wirz was even able to film two men playing end-blown ceremonial flutes at the Sentani Lake. In the 1930s, Gregory Bateson stayed at the middle Sepik and had the chance to try to play the ceremonial flutes himself. In 1936, he published the short article "Music of New Guinea" in the Magazine of St. Johns College, The Eagle. The article deals principally with ceremonial flutes of the Sepik and the implantation of their music in the socio-cultural system. It contains a transcription of a short piece of ceremonial music of the Iatmul. This transcription shows four phrases and each one is repeated several times. For the transcription, only one staff is used and there is no indication of which notes are played by which flute. However, comparing the notes of the transcription with the possible harmonic series, only the following setting would be possible: the longer flute sounds F-sharp4 and A-sharp4, whereas the shorter flute sounds only the G-sharp4. Bateson realized that there must be a corresponding notion between the system of how the two ceremonial flutes interact and the society's social structure.

"Whether the process of thought patterned by such a system has influenced the planning of the flute duet it is impossible to say for certain, but this sort of staggering is not common as a feature of social organisation and I do not know of any similar phenomenon in music." (Bateson, 1936: 159)

Systematic ethnomusicological research on the ceremonial flutes of the Sepik River region began with Gordon Spearritt's studies in the 1970s. He made several fieldtrips to the middle Sepik River region, recorded music (MacLennan, Spearritt, Schuster, 1981) and included large parts of precise transcriptions in his thesis (Spearritt, 1979 I and II). Spearritt did his main research on ceremonial flutes among the Nyaura and in the village Aibom. Also, the anthropologist Jürg Wassmann carried out field research among the Nyaura and published on the songs and the ethnography of this Iatmul group (Wassmann, 1982, 1987, 1991, 1999).

The Nyaura play the ceremonial flutes during the song cycles called sagi, which incorporates their most important historic and mythological information. The song cycles are performed during significant events such as the inauguration of a men's house (ngego) or family house (ngai sagi), the completion of work on a particular ca- 
noe (vala sagi), or after the death of an important group member (kitagamat or minjango).

The way the flutes are played by the two musicians is based on an alternating system, the two flautists stand close together, face each other and in alternation each one produces one sound (very rarely two). Due to the large size of the instruments the musicians must blow very hard to make them sound and it is impossible to produce more than a few notes in a row. Alternating in the sound production is the only way that allows the musicians physically to play melodies on these large flutes. The interlocking structure is also the basic form of the musical scale used by the two instruments. The two flutes differ in length in such a way that the interval of the two fundamentals is - more or less - a major second, and therefore the two harmonic series interlock. The following intervallic structure corresponds to the flute called Mariuamangi of the Nyaura. For the piece of music played on these two flutes, each instrument produces the harmonic series from 3 to 6 . The longer flute's fundamental is $\mathrm{Eb}$, and this flute plays the tones $\mathrm{Bb} 3$ (harmonic 3), Eb4 (harmonic 4), G4 (harmonic 5), Bb4 (harmonic $6)$. These tones combined with the harmonic series of the shorter flute in $\mathrm{F}$ and its harmonic $\mathrm{C} 4$ (harmonic 3), F4 (harmonic 4), A4 (harmonic 5), C5 (harmonic 6) provide the complete scale of $\mathrm{Bb}, \mathrm{C}, \mathrm{Eb}, \mathrm{F}, \mathrm{G}, \mathrm{A}, \mathrm{Bb}, \mathrm{C}$.

A musical analysis of Spearritt's transcribed pieces shows that the alternation or interlocking is also the major structural plan of the musical piece itself. Alternation is evident by large scale parts where two parts of several minutes alternate, by smaller musical sections, and even by the smallest musical motifs consisting of only a few notes. In some pieces this alternation is more evident than in others, but it is always the key for the understanding of the structural form of the relevant piece of music. The dualistic structure with interlocking processes dominates the ceremonial flute music, the rhythmical patterns of the wagen-drum and even of the semi-ceremonial mi-drum and it dominates the structure of the Iatmul society.

\section{Dualism in Iatmul society}

Whenever ceremonial music is performed at the middle Sepik, it has the function to build up a spiritual connection to the ancestral world and it seems obvious that there is an important and meaningful plan behind this music's form and structure.

For example, the Iatmul society is dualistic, metaphorically based on the image of a crocodile jaw. The upper part of the crocodile's jaw stands for heaven or father (nyoui) and includes the following entities: sun, day, stars, and trees. On the other hand, the lower part of the crocodile's jaw (nyame) stands for earth or mother and combines the entities like: darkness, earth, night, and pig. The Iatmul society is organized in patrilineal clans and each clan belongs to one of the two moieties either nyoui or nyame (Wassmann, 1988: 13).

Besides this dualistic structure, the social activities and the rules that regulate the society are based on an alternation process. For example, ego does not take his wife from the same clan as his father but from the same clan as his grandfather and ego receives the name of his grandfather and his son will receive the name of his father (Stanek, 1983: 171). In the spatial arrangement of village houses, each moiety is located on one side of the main path and the clan houses are arranged in an interlocking system according to the even or odd number of each clan in the clan group (Stanek, 1983: 75). Thinking of the two halves - moieties, partner clans, age groups, and individual people as two intermeshed gears, it seems that alternation is the driving element of this society. This idea and its representation in music, was assumed by Bateson in his short article on music of 1936 that is quoted earlier in this text ${ }^{12}$.

\section{Conclusion}

The particularity of the ceremonial music of the middle Sepik is its symbolic content on several levels. The instruments, drums and ceremonial flutes, represent the voice of ancestor spirits and at the same time their music represents the structure of the society. Equally, the songs refer to mythical times and mythical protagonists and at the same time the order of the song parts represents the structure of the society. Melodies and rhythms in the ceremonial music of the middle Sepik River do fulfill aesthetic expectations but it is also important that the music's structure does represent the society and refers to the ancestor world. Only in this combination ceremonial music helps to create the key moments in each ceremony, when the participants "feel" that their ancestor spirits are present.

12. Similar strong symbolism of the social life and belief system in the music can be found in other Melanesian regions, for example, in the flute music of the Waxei in Papua New Guinea (Yamada, 1997: 207), in the panpipes ensembles of the 'Aréaré on Malaita in the Solomon Islands (Zemp et Schwarz, 1973; Zemp, 1997), or in the ayoii song on the main islands (Grande Terre) of New Caledonia (Ammann, 1997: 134). 


\section{REFERENCES}

Ammann Raymond, 1996. Revival of the Ancient Kanak Flute, Kulele: Occasional Papers on Pacific Music and Dance 2, pp. 47-56.

—, 1997. Le rythme Kanak, Cahiers de musiques traditionnelles 11, pp. 237-247.

—, 1998. How Kanak is Kaneka Music, The Use of Traditional Percussion Instruments in the Modern Music of the Melanesians in New Caledonia, The World of Music. Old Instruments in New Contexts. Case Studies of Innovation and Appropriation 40 (2) pp. 9-27.

—, 2007. Nose flutes in Melanesia, Facts or Fairytales, in R. Moyle (ed.), Oceanic Music Encounters, the Print Resource and the Humans Resource, Essays in Honour of Mervyn McLean, Research in Linguistics and Anthropology, Department of Anthropology, The University of Auckland, New Zealand, pp. 3-14.

-, 2012. Sounds of Secrets, Field Notes on Ritual Music and Musical Instruments on the Islands of Vanuatu, Münster, Lit Verlag.

—, 2013. String Bands in Vanuatu: Pop or Ethno?, in G. Grupe (ed.), Ethnomusicology and Popular Music Studies, Grazer Beiträge zur Ethnomusikologie 25, pp. 39-52.

Bateson Gregory, 1936. Music in New Guinea, The Eagle 48, pp. 158-170.

Bogner Piet, 1984. Traditionelle Musikinstrumente aus Neuguinea, München, Gesellschaft zur Erforschung der Naturvölker, GEN News 84 (2).

Crowdy Denis, 2005. Guitar Style, Open Tunings, and Stringband Music in Papua New Guinea, Boroko, Institute of Papua New Guinea Studies, Apwitihire 9.

Edge-Partington James, 1969. An Album of the Weapons, Tools, Ornaments, Articles of Dress of the Natives of the Pacific Islands, Facsimile of 189098, parts 1-3, London, The Holland Press.

Fischer Hans, 1958. Schallgeräte in Ozeanien: Bau und Spieltechnik - Verbreitung und Funktion, Strasbourg, Baden-Baden, Heitz.

-, 1983. Sound-Producing Instruments in Oceania (Philip Holzknecht trans.), Boroko, Institute of Papua New Guinea Studies.

Gourlay Kenneth, 1975. Sound-Producing Instruments in Traditional Society, a Study of Esoteric Instruments and their Role in Male-Female Relations, Port Moresby/Canberra, Australian National University, New Guinea Research Bulletin 60.
GraF Walter, 1947.Zur Spieltechnik und Spielweise von Zeremonialflöten von der Nordküste Neuguineas, Archiv für Völkerkunde 2, pp. 87-100.

-, 1950. Die Musikwissenschaftlichen Phonogramme Rudolf Pöchs von der Nordküste Neu Guineas, Wien, Österreichische Akademie der Wissenschaften.

Hornbostel V. Moritz and Curt SACHS, 1914. Systematik der Musikinstrumente, Zeitschrift für Ethnologie 9, pp. 553-590.

Juillerat Bernard, 1996 [1995]. Air, Fire Sound: The Construction and Use of Trumpets and Drums in the Border Mountains (Papua New Guinea), Kulele: Occasional Papers on Pacific Music and Dance 2, pp. 1-30.

Kunst Jaap, 1931. A Study on Papua Music, Weltevreden, G. Kolff \& Co.

McLean Mervyn, 1994. Diffusion of Musical Instruments and Their Relations to Language Migrations in New Guinea, Institute of Papua New Guinea Studies, Boroko, Kulele: Occasional Papers on Pacific Music and Dance 1 (Don Niles ed.).

Neunauss Richard, 1911. Deutsch-Neu-Guinea, Vol. I-III, Berlin, Reimer.

Niles Don, 2006. Drums, in P. Peltier and F. Morin (eds), Shadows of New Guinea, Art from the Great Island of Oceania in the Barbier-Mueller Collections, Geneva, Musée Barbier-Mueller Publications, pp. 322-351.

Patocchi Claudio, 1990 (unpubl.). Form und Funktion der Schlitztrommel am Mittelsepik, MA Thesis, University of Basel.

Peltier Philippe, Markus Schindlbeck et Christian Kaufmann (éds), 2015. Sepik. Arts de Papouasie Nouvelle-Guinée, Paris, Skira, musée du quai Branly.

Reche Otto, 1913. Der Kaiserin Augusta Fluss, in Georg Thilenius (ed.), Ergebnisse der SüdseeExpedition 1908-1910, Teil II Ethnograpie-A Melanesien, Band I, Hamburg, Friederichsen.

Roesicke Adolf, 1914. Mitteilungen über ethnographische Ergebnisse der Kaiserin-AugustaFluss-Expedition, Zeitschrift für Ethnologie 46, pp. 507-522.

Schmidt Andrea, 1998. Paul Wirz. Ein Wanderer auf der Suche nach der "wahren Natur", Basel, Ethnologisches Seminar der Universität, Wepf, Basler Beiträge zur Ethnologie 39.

Somerville Boyle T., 1897. Ethnographical Notes in New Georgia, Solomon Islands, Journal of the Royal Anthropological Institute 26, pp. 357-412. 
Spearritt Gordon, 1979 (unpubl.). The Music of the Iatmul People of the Middle Sepik River (Papua New Guinea) with Special Reference to Instrumental Music at Kandingai and Aibom. Ph. D. Dissertation, University of Queensland.

—, 1982. The Pairing of Musicians and Instruments in Iatmul Society, Yearbook for Traditional Music 14, pp. 106-125.

-, 2009. Music of the Ancestors. A Study of the Traditional Instrumental Music of the Iatmul of Papua New Guinea, DVD, ISBN 978-0-646-52536-5.

Staner Milan, 1983. Sozialordnung und Mythik in Palimbei, Bausteine zur ganzheitlichen Beschreibung einer Dorfgemeinschaft der Iatmul East Sepik Province, Papua New Guinea, Basel, Ethnologisches Seminar der Universität, Basler Beiträge zur Ethnologie 23.

Wassmann Jürg, 1982. Der Gesang an den Fliegenden Hund: Untersuchungen zu den totemistischen Gesängen und geheimen Namen des Dorfes Kandingei am Mittelsepik (Papua Neuguinea) anhand der "kirugu"-Knotenschnüre, Basel, Ethnologisches Seminar der Universität, Basler Beiträge zur Ethnologie 22.

—, 1987. Der Biss des Krokodils: Die ordnungsstiftende Funktion der Namen in der Beziehung zwischen Mensch und Umwelt am Beispiel der Initiation der Nyaura, Mittelsepik, in M. Münzel (ed.), Nutzung und Deutung der Umwelt, Frankfurt Main, Museum für Völkerkunde, pp. 511-557.

—, 1988. Der Gesang an das Krokodil: Die rituellen Gesänge des Dorfes Kandingei an Land und Meer, Pflanzen und Tiere (Mittelsepik, Papua New Guinea), Basel, Ethnologisches Seminar der Universität, Basler Beiträge zur Ethnologie 28.

-, 1991. The song to the flying fox: the public and esoteric knowledge of the important men of Kandingei about totemic songs, names and knotted cords (Middle Sepik, Papua New Guinea) (D.Q. Stephenson transl.), Boroko, National Research Institute, Cultural Studies Division, Apwitihire 2.

-, 1999. The Nyaura Concepts of Space and Time, in N. Lutkehaus et al. (eds), Sepik Heri- tage: Tradition and Change in Papua New Guinea, Durham, Carolina Academic Press, pp. 22-35.

Weвв Michael,1993. Lokal Musik. Lingua Franca. Songs and Identity in Papua New Guinea, Boroko, National Research Institute, Cultural Studies Division, Apwitihire 3.

WIRz Paul, 1952. A Description of Musical Instruments from Central North-Eastern New Guinea, Amsterdam, Koninklijk Instituut voor de Tropen Amsterdam, Mededeling C, Afdeling Culturele en Physische Anthropologie 43.

—, 1954. Über sakrale Flöten und Pfeifen des SepikGebietes (Neuguinea), Verhandlungen der Naturforschenden Gesellschaft in Basel 65, pp. 97-105.

-, 1959. Kunst und Kult des Sepik-Gebietes (NeuGuinea) unter besonderer Berücksichtigung einer daselbst in den Jahren 1950 und 1953 erworbenen Sammlung, Amsterdam, Koninklijk Instituut voor de Tropen Amsterdam, Mededeling 133, Afdeling Culturele en Physische Anthropologie 62.

Yamada Yoichi, 1997. Songs of Spirits: An Ethnography of Sounds in a Papua New Guinea Society, (Jun'ichi Ohno trans.), Boroko, Institute of Papua New Guinea Studies, Apwitihire 5.

Zemp Hugo, 1997. Composer et Interpréter des rythmes. Musique et langage tambouriné chez les 'Aréaré, Cahiers de Musiques Traditionnelles 10, pp. 191-235.

Zemp Hugo et Christian Kaufmann, 1969. Pour une transcription automatique des "langues tambourinés " mélanésiens (un exemple Kwoma, Nouvelle-Guinée), L'Homme, Revue française d'anthropologie 9 (2), pp. 38-88

Zemp Hugo et J. Schwarz, 1973. Échelles équiheptaphonic des flûtes de Pan chez les 'Aréaré (Malaita, Iles Salomon), Yearbook of the International Folk Music Council 5, pp. 85-121.

\section{DISCOGRAPHY}

MacLennan Robert, Gordon Spearritt and Meinhard Schuster, 1981. (LP) Music of Oceania: The Iatmul of Papua Niugini, Kassel, Bärenreiter Musicaphon, 30 SL 2701. 